Hal. 259 - 270

\title{
DETERMINAN TINGKAT PENGUNGKAPAN TANGGUNG JAWAB SOSIAL PERUSAHAAN MANUFAKTUR SUB SEKTOR MAKANAN DAN MINUMAN DI BEI
}

\author{
Marmono Singgih \\ Fakultas Ekonomi dan Bisnis Universitas Jember \\ marmono.singgih@gmail.com \\ Lilik Farida \\ Fakultas Ekonomi dan Bisnis Universitas Jember \\ Lilikfarida100@gmail.com \\ Rizqi Akbar Iwanda \\ Fakultas Ekonomi dan Bisnis Universitas Jember \\ Akbarrizqi95@gmail.com
}

\begin{abstract}
The Corporate social responsibility (CSR) is a program designed to balance the company's economic profits and its contribution to the economy, social, community, and environment. Food and beverage companies have a high production level that produces waste harmful of the people's lives. Public needs the information to what extent the company runs its CSR activities so the people's right to live safely and healthily, the employee welfare, and the product safety is met. If the community perceives that the company neglects the social and environmental aspects, has no contribution to the community, and even causes a negative impact, it will lead to community resistance. Therefore, the disclosure of a company's CSR activities is crucial. The research population was all manufacturing companies in food and beverages subsector listed on the Indonesia Stock Exchange in 2012-2015. There were 14 companies registered in 2012-2015 with the number of observations consisted of 56 companies' annual reports. The sample was taken using purposive sampling method. Results show that profitability, company size, and public ownership have a significant effect on the level of CSR disclosure, while leverage and commissioners have no significant effect on the level of CSR disclosure.
\end{abstract}

Keywords: CSR, Level of CSR Disclosure.

Abstrak: Program CSR atau tanggung jawab sosial perusahaan merupakan salah satu program penyeimbang antara keuntungan ekonomi dan kontribusi terhadap ekonomi, sosial, masyarakat, dan lingkungan. Perusahaan makanan dan minuman memiliki tingkat produksi yang tinggi dan menghasilkanlimbah produksi yang dapat mengganggu kehidupan masyarakat sekitar. Oleh karena itu, masyarakat membutuhkan informasi mengenai sejauh mana perusahaan melaksanakan aktifitas CSR sehingga hak masyarakat untuk hidup aman dan tentram, kesejahteraan karyawan, dan keamanan mengkonsumsi makanan dan minuman dapat terpenuhi. Jika masyarakat menganggap bahwa perusahaan tidak memperhatikan aspek sosial dan lingkungan, tidak merasakan kontribusi perusahaan secara langsung, bahkan merasakan dampak negatif dari beroperasinya sebuah perusahaan, maka akan menimbulkan resistensi masyarakat. Karenanya, pengungkapan CSR merupakan hal sangat krusial.Populasi penelitian ini 
adalah seluruh perusahaan manufaktur sub sektor makanan dan minuman yang terdaftar di Bursa Efek Indonesia (BEI) periode 20122015. Ada 14 (empat belas) perusahaan manufaktur sub sektor makanan dan minuman yang terdaftar pada periode 2012-2015 dengan jumlah observasi sebanyak 56 laporan tahunan perusahaan. Penentuan sampel dilakukan dengan metode purposive sampling.Hasil penelitian menunjukkan bahwa profitabilitas, ukuran perusahaan, dan kepemilikan publik berpengaruh signifikan terhadap tingkat pengungkapan CSR, sementara leverage dan dewan komisaris tidak berpengaruh signifikan terhadap tingkat pengungkapan CSR perusahaan.

Kata Kunci: CSR, Level Pengungkapan CSR.

\section{Pendahuluan}

Program CSR (Corporate Social Responsibility) atau tanggung jawab sosial perusahaan merupakan salah satu sarana bagi perusahaan untuk menyeimbangkan antara keuntungan ekonomi dengan kontribusinya bagi ekonomi masyarakat, sosial, dan lingkungan demi mewujudkan pembangunan berkelanjutan (pustaka.pu.go.id). Perusahaan dituntut untuk memberikan informasi kegiatan yang dijalankan seperti yang telah disebutkan diatas secara transparan sebagai wujud tanggung jawab sosial. Namun, meski telah ditetapkan peraturan-peraturan yang mengatur pelaksanaan CSR, peraturan-peraturan tersebut tidak memberikan pedoman khusus mengenai bagaimana dan informasi apa saja yang harus dilaporkan oleh perusahaan mengenai pelaksanaan CSR sehingga pengungkapan yang memadai terkait dengan kegiatan CSR hanya berlatar kebutuhan perusahaan untuk membuat image bahwa dalam pandangan stakeholder perusahaan memiliki kepedulian terhadap lingkungan sosial dan lingkungan hidup (Hernitra, 2011). Hingga kini belum terdapat kesepakatan standar pelaporan CSR yang dapat dijadikan acuan bagi perusahaan dalam menyampaikan laporan CSR sehingga menyulitkan pengguna laporan tahunan untuk melakukan evaluasi (Jalal, 2007).

Perusahaan makanan dan minuman memiliki tingkat produksi yang tinggi. Dalam proses produksinya perusahaan ini juga menyumbangkan limbah produksi terhadap lingkungan. Hal tersebut dapat pula mengganggu kehidupan masyarakat sekitar pabrik. Untuk itu masyarakat membutuhkan informasi mengenai sejauh mana perusahaan sudah melaksanakan aktifitas sosialnya sehingga hak masyarakat untuk hidup aman dan tentram, kesejahteraan karyawan, dan keamanan mengkonsumsi makanan dan minuman dapat terpenuhi. Oleh karena itu program CSR perlu diperhatikan oleh perusahaan sebagai sarana pertanggungjawaban atas aktifitas produksi terhadap masyarakat dan pemegang saham. Jika masyarakat menganggap perusahaan tidak memperhatikan aspek sosial dan lingkungannya serta tidak merasakan kontribusi secara langsung bahkan merasakan dampak negatif dari beroperasinya sebuah perusahaan maka akan menimbulkan resistensi 
masyarakat., karenanya pengungkapan CSR merupakan hal penting yang harus diperhatikan perusahaan.

Penelitian tentang pengungkapan CSR pernah dilakukan sejumlah peneliti dengan hasil yang beragam. Rahmatika Marterda (2011) dalam penelitiannya dengan sampel 96 perusahaan manufaktur yang terdaftar di BEl 2008-2009 menunjukkan adanya hubungan positif antara pengungkapan CSR dengan profitabilitas dan tidak menemukan adanya pengaruh ukuran perusahaan dan leverage terhadap pengungkapan CSR. Berbeda dengan penelitian Priantinah dan Nur (2012) dengan sampel 66 perusahaan deri 177 populasi perusahaan berkategori high profile yang terdaftar di BEI periode 2008-2010 yang menunjukkan hasil sebaliknya bahwa ukuran perusahaan, dewan komisaris, dan leverage berpengaruh negatif terhadap pengungkapan CSR sedangkan untuk profitabilitas, kepemilikan saham publik, dan pengungkapan media menunjukkan tidak adanya pengaruh terhadap CSR. Sedangkan dalam penelitiannya Wijaya (2012) dengan sampel 11 perusahaan manufaktur yang terdaftar di BEI di tahun 2008-2010 menemukan bukti bahwa ukuran perusahaan berpengaruh terhadap pengungkapan CSR sedangkan leverage, profitabilitas, ukuran dewan komisaris, dan kinerja lingkungan tidak berpengaruh terhadap pengungkapan CSR. Berdasarkan penelitian-penelitian sebelumnya tentang pengungkapan CSR, ditemukan beberapa variabel yang hasilnya tidak konsisten antara peneliti satu dengan peneliti lainnya. Oleh karena itu, peneliti menguji konsistensi variabel leverage, profitabilitas, ukuran perusahaan, kepemilikan publik, dan dewan komisaris sebagai determinan tingkat pengungkapan.

\section{Metodologi}

\section{Identifikasi Variabel: independen dan dependen}

a. Leverage (X1)

Leverage dapat diartikan sebagai kemampuan perusahaan dalam melunasi semua kewajiban dengan ekuitasnya. Indikator yang digunakan untuk mengukur tingkat leverage adalah Debt To Equity Ratio (DER). Skala pengukuran yang digunakan untuk variabel leverage adalah skala rasio. Adapun pengukurannya menggunakan rumus sebagai berikut:

$$
\mathrm{DER}=\frac{\text { debt }}{\text { equity }}
$$

b. Profitabilitas (X2)

Profitabilitas dapat diartikan sebagai kemampuan perusahaan memperoleh laba dan sejauh mana keefektifan pengelolaan perusahaan. Indikator yang digunakan untuk mengukur tingkat profitabilitas adalah Return On Assets (ROA). Skala 
pengukuran yang digunakan untuk variabel prifitabilitas adalah skala rasio Adapun pengukurannya menggunakan rumus sebagai berikut:

$$
\text { Return On Asset }=\frac{E A T}{\text { Total Asset }}
$$

c. Ukuran Perusahaan (X3)

Ukuran perusahaan dapat diartikan sebagai skala perusahaan yang dilihat dari total aktiva perusahaan pada akhir tahun. Total penjualan juga dapat diguanakan untuk mengukur besarnya perusahaan. Indikator yang digunakan untuk mengukur tingkat ukuran perusahaan adalah total asset/total aktiva. Skala pengukuran yang digunakan untuk variabel ukuran perusahaan adalah skala rasio. Adapaun pengukurannya menggunakan rumus sebagai berikut:

$$
\text { Size }=\text { Total asset }
$$

d. Kepemilikan Publik (X4)

Kepemilikan publik dapat diartikan sebagai prosentase kepemilikan saham yang dimiliki pihak luar. Indikator yang digunakan untuk mengukur tingkat kepemilikan publik adalah prosentase outsider stakeholder. Skala pengukuran yang digunakan untuk variabel kepemilikan publik adalah skala rasio Adapun pengukurannya menggunakan rumus sebagai berikut:

\section{Structure of stock ownership = outsider stakeholder}

e. Ukuran Dewan Komisaris (X5)

Dewan komisaris adalah banyaknya jumlah anggota dewan komisaris dalam suatu perusahaan. Indikator yang digunakan untuk mengukur tingkat dewan komisaris adalah jumlah dewan komisaris yang terdapat di perusahaan tersebut. Skala pengukuran yang digunakan untuk variabel dewan komisaris adalah skala rasio. Adapun pengukurannya menggunakan rumus sebagai berikut:

$$
D K=\Sigma \text { The board of manager }
$$

\section{f. CSR Disclosure}

Variabel dependen dalam penelitian adalah CSR Disclosure dengan menggunakan indikator dari Global Reporting Initiative (GRI) dengan jumlah 79 pengungkapan Pengukuran ini digunakan juga dalam penelitian sebelumnya yang dilakukan oleh Priantinah dan Nur (2012). Total information item of CSR disclosure

$$
\text { CSRDI }=\frac{\text { Total item information of CSR disclosure }}{79 \text { item information of CSR GRI } 2007 \text { version }}
$$

\section{Populasi dan Sampel}

Populasi dalam penelitian ini adalah seluruh perusahaan manufaktur sub sektor makanan dan minuman yang terdaftar di BEI pada periode 2012-2015. Berdasarkan data yang ada di $\mathrm{BEl}$, terdapat 14 perusahaan manufaktur sub sektor makanan dan minuman 
yang terdaftar pada periode 2012-2015 dengan jumlah observasi sebanyak 56 laporan tahunan perusahaan. Penentuan sampel dilakukan dengan metode purposive sampling, dimana dalam metode tersebut ditetapkan kriteria-kriteria tertentu yang akan menentukan jumlah sampel yang valid untuk diteliti.

\section{Metode Analisis Data}
a. Analisis Statistik Deskriptif
b. Uji Normalitas Data
c. Analisis Regresi Linier Berganda

Analisis ini digunakan untuk mengetahui pengaruh variabel independen terhadap variabel dependen. Dengan persamaan sebagai berikut :

$$
Y=A+B_{1} X_{1}+B_{2} X_{2}+B_{3} X_{3}+B_{4} X_{4}+B_{5} X_{5}+E
$$

Keterangan :

$$
\begin{array}{ll}
\mathrm{Y} & \text { : Corporate social responsibility } \\
\mathrm{a} & : \text { Konstanta } \\
\mathrm{b}_{1}-\mathrm{b}_{6} & \text { : Koefisien Regresi } \\
\mathrm{X}_{1} & : \text { Leverage } \\
\mathrm{X}_{2} & : \text { Profitabilitas } \\
\mathrm{X}_{3} & : \text { Ukuran Perusahaan } \\
\mathrm{X}_{4} & \text { : Kepemilikan Publik } \\
\mathrm{X}_{5} & \text { : Dewan Komisaris } \\
\mathrm{E} & : \text { Kesalahan Regresi }
\end{array}
$$

\begin{tabular}{|c|c|c|c|c|c|}
\hline & $\mathrm{N}$ & Minimum & Maximum & Mean & Std. Deviation \\
\hline Leverage & 56 & .0049 & 3.0300 & .576804 & 6634073 \\
\hline Profitabilitas & 56 & .0080 & .6700 & .115089 & 1296991 \\
\hline Ukuran Perusahaan & 56 & 2 & 91.0 & 8.975 & 20.5039 \\
\hline Kepemilikan Publik & 56 & .0400 & 6707 & 266077 & .1709355 \\
\hline Dewan Komisaris & 56 & 2 & 8 & 4.59 & 1.952 \\
\hline$\overline{\mathrm{CSR}}$ (GRI) & 56 & .177215 & .367089 & .25565099 & .044339597 \\
\hline
\end{tabular}

d. Uji Asumsi Dasar Klasik

\section{Hasil dan Pembahasan}

Statistik diskriptif Pengungkapan Corporate social responsibility (CSR) dan leverage,profitabilitas, ukuran perusahaan, Kepemilikan Publik, dan dewan komisaris, sebagai berikut:

Berdasarkan hasil analisis dengan menggunakan statistik deskriptif terhadap luas

Valid N (listwise) 56

pengungkapan Corporate social responsibility (CSR) menunjukkan nilai minimum sebesar 
0,177215 dan nilai maksimum sebesar 0,367089. Hal ini berarti bahwa perusahaan paling sedikit mengungkapkan CSR dalam laporan tahunan (annual report) sebesar 17,72\% yaitu PT Prasidha Aneka Niaga Tbk pada tahun 2012 dan paling banyak mengungkapkan CSR adalah PT Indofood Sukses Makmur Tbk pada tahun 2015 sebesar 36,70\%. Jika diambil rata-rata dari semua sampel, pengungkapan CSR yang dilakukan oleh perusahaan sebesar 25,56\%. Standar deviasi sebesar 0,044339597 menunjukkan variasi yang terdapat dalam indeks. Besarnya indeks menunjukkan besar pengungkapan tanggung jawab sosial oleh perusahaan. Semakin besar nilai variabel pengungkapan CSR artinya perusahaan lebih banyak melakukan pengungkapan item CSR.

Hasil analisis dengan menggunakan statistik deskriptif terhadap leverage menunjukkan nilai minimum sebesar 0,0049 dan nilai maksimum sebesar 3,0300. Hal ini berarti bahwa DER yang paling rendah dalam sampel perusahaan sebesar $0,49 \%$ yaitu pada PT Indofood CBP Sukses Makmur Tbk pada tahun 2012 dan paling tinggi pada PT Multi Bintang Indonesia Tbk pada tahun 2014 sebesar 303\%. Semakin besar nilai DER berarti semakin besar leverage. Rata-rata nilai leverage yang ada pada sampel perusahaan adalah 0,576804 . Standar deviasi sebesar 0,6634073 menunjukkan variasi yang terdapat dalam leverage.

Hasil analisis dengan menggunakan statistik deskriptif terhadap profitabilitas menunjukkan nilai minimum sebesar 0,0080 dan nilai maksimum sebesar 0,6700. Hal ini berarti bahwa ROA yang paling rendah dalam sampel perusahaan sebesar $0.8 \%$ yaitu pada PT Tri Banyan Tirta Tbk pada tahun 2014, 2015 dan paling tinggi pada PT Multi Bintang Indonesia Tbk pada tahun 2013 sebesar 67\%. Semakin besar nilai ROA berarti semakin tinggi profitabilitas perusahaan. Rata-rata nilai profitabilitas yang ada pada sampel perusahaan adalah 0,115089. Standar deviasi sebesar 0,1296991 menunjukkan variasi yang terdapat dalam profitabilitas.

Hasil analisis dengan menggunakan statistik deskriptif terhadap ukuran perusahaan menunjukkan nilai minimum sebesar 0,2 dan nilai maksimum sebesar 91,0. Hal ini berarti bahwa log total aset perusahaan yang paling sedikit dalam sampel perusahaan sebesar 0,2 yaitu PT Sekar Bumi Tbk dan PT Sekar Laut Tbk pada tahun 2012 sedangkan yang paling tinggi sebesar 91,0 yaitu PT Indofood Sukses Makmur Tbk pada tahun 2015. Semakin besar nilai log total aset perusahaan berarti semakin besar ukuran perusahaan. Rata-rata nilai ukuran perusahaan yang ada pada sampel perusahaan adalah 8,975. Standar deviasi sebesar 20,5039 menunjukkan variasi yang terdapat dalam ukuran perusahaan.

Hasil analisis dengan menggunakan statistik deskriptif terhadap kepemilikan publik menunjukkan nilai minimum sebesar 0,0400 dan nilai maksimum sebesar 0.6700 . Hal ini berarti bahwa persentase outsider stakeholders yang paling sedikit dalam sampel perusahaan sebesar 0,4\% yaitu PT Sekar Laut Tbk pada tahun 2012-2015 dan paling tinggi 
sebesar 67,07\% yaitu PT Mayora Indah Tbk pada tahun 2012-2015. Semakin besar nilai persentase suatu perusahaan berarti semakin meningkatnya nilai perusahaan. Rata-rata nilai ukuran perusahaan yang ada pada sampel perusahaan adalah 0,266077. Standar deviasi sebesar 0,1709355 menunjukkan variasi yang terdapat dalam kepemilikan publik.

Hasil analisis dengan menggunakan statistik deskriptif terhadap ukuran dewan komisaris menunjukkan nilai minimum sebesar 2 dan nilai maksimum sebesar 8 . Hal ini berarti bahwa jumlah dewan komisaris yang paling sedikit dalam sampel perusahaan sebanyak 2 orang yaitu pada PT Siantar Top Tbk pada tahun 2012-2015 dan paling banyak yaitu pada PT Indofood CBP Sukses Makmur pada tahun 2012, PT Indofood Sukses Makmur Tbk pada tahun 2012-2015, PT Multi Bintang Indoneia Tbk sebayak 8 orang. Semakin besar nilai ukuran dewan komisaris berarti jumlah anggota dewan komisaris semakin banyak. Rata-rata jumlah dewan komisaris yang ada pada sampel perusahaan adalah 4,59 orang. Standar deviasi sebesar 1,952 menunjukkan variasi yang terdapat dalam ukuran dewan komisaris.

Hasil uji normalitas data menggunakan Log atau LN, data berdistribusi normal, dengan rincian sebagai berikut:

\begin{tabular}{llll}
\hline \multicolumn{1}{c}{ Variabel } & \multicolumn{1}{c}{ Mean } & \multicolumn{1}{c}{ Std. Deviasi } & \multicolumn{1}{c}{ Keterangan } \\
\cline { 1 - 2 } Leverage & $-2,0667$ & 2,25335 & Berdistribusi normal \\
\hline Profitabilitas & $-2,5618$ & 0,89704 & Berdistribusi normal \\
\hline Ukuran Perusahaan & 0,6931 & 1,56563 & Berdistribusi normal \\
\hline Kepemilikan Publik & $-1,5480$ & 0,72057 & Berdistribusi normal \\
\hline Dewan Komisaris & 1,4339 & 0,42981 & Berdistribusi normal \\
\hline CSR & $-1,3783$ & 0,17055 & Berdistribusi normal \\
\hline
\end{tabular}

Hasil Analisis Regresi Linier Berganda, dapat dilihat pada tabel berikut:

\begin{tabular}{lll}
\hline \multicolumn{1}{c}{ Variabel } & Koefisien Unstandarized & Koefisien Standarized \\
\hline Konstanta & $-1,487$ & 0,071 \\
\hline Leverage & 0,005 & 0,312 \\
\hline Profitabilitas & 0,059 & 0,745 \\
\hline Ukuran Perusahaan & 0,081 & 0,351 \\
\hline Kepemilikan Publik & $-0,083$ & 0,152 \\
\hline Dewan Komisaris & 0,060 & \\
\hline
\end{tabular}

Berdasarkan hasil Analisis Regresi Linier Berganda diperoleh persamaan sebagai berikut:

$$
Y=-1,487+0,005 X_{1}+0,059 X_{2}+0,081 X_{3}-0.083 X_{4}+0,000 X_{5}+e
$$


Keterangan:

$\mathrm{Y} \quad$ = Pengungkapan Corporate social responsibility

$\mathrm{X}_{1}=$ Leverage

$\mathrm{X}_{2}=$ Profitabilitas

$\mathrm{X}_{3}=$ Ukuran Perusahaan

$\mathrm{X}_{4}=$ Kepemilikan Publik

$\mathrm{X}_{5} \quad=$ Dewan Komisaris

Dari persamaan diatas dapat diketahui bahwa nilai konstanta adalah sebesar -1,487 yang artinya apabila variabel independen lainnya diasumsikan tetap maka pengungkapan corporate social responsibility menurun sebesar -1,487. Persamaan diatas juga menunjukkan besarnya koefisien regresi dari masing-masing variabel independen.

Hasil uji normalitas model, menunjukkan bahwa nilai probabilitas dari uji kolmogrov smirnov yaitu 0,925. Angka tersebut menunjukkan jumlah $>0,1$ yang berarti bahwa data yang digunakan dalam penelitian ini terdistribusi normal.

Hasil uji autokorelasi, dirinci dalam tabel berikut:

\begin{tabular}{lcllll}
\hline Model & $R$ & $R$ Square & $\begin{array}{c}\text { Adjusted } R \\
\text { Square }\end{array}$ & $\begin{array}{c}\text { Std. Error of the } \\
\text { Estimate }\end{array}$ & Durbin-Watson \\
\hline 1 & 0,773 & 0,597 & 0,557 & 0,11354 & 1,337 \\
\hline
\end{tabular}

Hasil Durbin Waston tersebut didapat angka 1,337. Angka tersebut menunjukkan bahwa tidak terjadi autokorelasi. Hal ini sesuai dengan syarat pengambilan keputusan bahwa angka 1,337 berada diantara -2 dan +2 yang berarti suatu model regresi tidak terjadi autokorelasi.

Hasil uji multikolinieritas, dirinci dalam tabel berikut:

\begin{tabular}{lll}
\hline \multicolumn{1}{c}{ Variabel } & Tolerance & Variance Inflation Factor \\
\hline Leverage & 0,761 & 1,313 \\
\hline Profitabilitas & 0,695 & 1,440 \\
\hline Ukuran Perusahaan & 0,225 & 4,442 \\
\hline Kepemilikan Publik & 0,386 & 2,593 \\
\hline Dewan Komisaris & 0,368 & 2,718 \\
\hline
\end{tabular}

Berdasarkan tabel hasil uji multikolinieritas dapat diketahui bahwa nilai Tolerance semua variabel independen (leverage, profitabilitas, ukuran perusahaan, Kepemilikan Publik, dan dewan komisaris) lebih besar daripada 0,10 dan nilai Variance Inflation Factor (VIF) demua variabel independen (leverage, profitabilitas, ukuran perusahaan, kepemilikan publik, dan 
dewan komisaris) lebih kecil daripada 10,00. Maka, dapat disimpulkan tidak terjadi multikolineritas.

Uji heteroskedastisitas dalam penelitian dilakukan dengan cara melihat grafik scatterplot. Jika ada pola tertentu, seperti titik-titik yang ada membentuk pola tertentu yang teratur (bergelombang, melebar kemudian menyempit), maka mengindikasikan telah terjadi heteroskedastisitas. Sebaliknya, jika tidak ada pola yang jelas, serta titik-titik menyebar diatas dan dibawah angka 0 pada sumbu $\mathrm{Y}$, maka tidak terjadi heterokedastisitas Berdasarkan grafik scatterplot terlihat bahwa titik-titik menyebar secara acak serta tersebar baik diatas maupun dibawah angka 0 pada sumbu $\mathrm{Y}$, dan dinyatakan tidak terjadi heteroskedastisitas pada model regresi.

Hasil Uji Hipotesis terinci dalam tabel berikut:

\begin{tabular}{|c|c|c|c|c|}
\hline Variabel & t tabel & A & B & Keterangan \\
\hline Leverage & 1,296 & 0,689 & 0,071 & $\begin{array}{l}\text { Tidak berpengaruh signifikan } \\
\text { negatif }\end{array}$ \\
\hline Profitabilitas & 1,296 & 2,893 & 0,312 & Berpengaruh signifikan positif \\
\hline Ukuran Perusahaan & 1,296 & 3,937 & 0,745 & Berpengaruh signifikan positif \\
\hline Kepemilikan Publik & 1,296 & $-2,430$ & $-0,351$ & Berpengaruh signifikan negatif \\
\hline Dewan Komisaris & 1,296 & 1,026 & 0,152 & $\begin{array}{l}\text { Tidak berpengaruh signifikan } \\
\text { positif }\end{array}$ \\
\hline
\end{tabular}

Dari tabel diatas dapat diketahui bahwa nilai t hitung $(0,689)$ lebih kecil dari nilai t tabel $(1,296853)$, maka HO diterima, berarti variabel leverage perusahaan tidak berpengaruh negatif signifikan terhadap CSR perusahaan manufaktur sub sektor makanan dan minuman. Pengaruh variabel profitabilitas (X2) terhadap CSR diketahui bahwa nilai t hitung $(2,893)$ lebih besar dari nilai t tabel $(1,296853)$, maka $\mathrm{HO}$ ditolak, berarti variabel profitabilitas perusahaan berpengaruh positif signifikan terhadap CSR perusahaan manufaktur sub sektor makanan dan minuman. Pengaruh variabel ukuran perusahaan (X3) terhadap CSR (Y) diketahui bahwa nilai t hitung $(3,937)$ lebih besar dari nilai t tabel $(1,296853)$, maka HO ditolak, berarti variabel ukuran perusahaan berpengaruh positif signifikan terhadap CSR perusahaan manufaktur sub sektor makanan dan minuman. Pengaruh variabel kepemilikan publik (X4) terhadap CSR (Y) diketahui bahwa nilai t hitung $(-2,430)$ negatif lebih besar dari nilai t tabel $(1,296853)$, maka $\mathrm{H} 0$ ditolak, berarti variabel kepemilikan publik perusahaan berpengaruh negatif signifikan terhadap CSR perusahaan manufaktur sub sektor makanan dan minuman. Pengaruh variabel dewan komisaris (X5) terhadap CSR (Y) diketahui bahwa nilai t hitung $(1,026)$ lebih kecil dari nilai $t$ tabel $(1,296853)$, maka $\mathrm{H} 0$ diterima, berarti variabel 
dewan komisaris perusahaan tidak berpengaruh positif signifikan terhadap CSR perusahaan manufaktur sub sektor makanan dan minuman.

Berdasarkan hasil content analysis yang dilakukan terhadap 56 laporan tahunan perusahaan sampel yang terdaftar di BEI tahun 2012-2015, diperoleh hasil yang menggambarkan tingkat pengungkapan CSR pada laporan tahunan perusahaanperusahaan manufaktur sub sektor makanan dan minuman, umlah pengungkapan paling luas dilakukan oleh PT. Indofood Sukses Makmur Tbk. yaitu sebanyak 109 item dengan rincian 24 item pada tahun 2012, 28 item pada 2013, 28 item pada 2014, dan 29 item pada 2015. Sedangkan paling sedikit adalah 71 item dengan rincian 15 dan 17 item pada tahun 2012, 19 dan 16 item pada tahun 2013, 18 dan 19 item pada 2014, dan 19 item pada tahun 2015 dari total pengungkapan yang dilakukan oleh PT. Tiga Pilar Sejahtera Food,Tbk dan PT. Tri Banyan Tirta, Tbk. Masih rendahnya tingkat pengungkapan CSR yang dilakukan perusahaan di Indonesia ini berarti menunjukkan bahwa peraturan yang dibuat oleh pemerintah masih belum efektif. Perusahaan kemungkinan akan melakukan kegiatan CSR dan pengungkapan CSR hanya untuk memenuhi aturan yang telah ditetapkan oleh badan regulasi seperti Pemerintah, BEI, dan Bapepam.

Berdasarkan hasil pengujian pengaruh variabel leverage terhadap tingkat pengungkapan CSR, dapat diketahui bahwa variabel leverage secara statistik tidak berpengaruh secara signifikan terhadap tingkat pengungkapan CSR. Ketergantungan perusahaan terhadap utang dalam membiayai kegiatan operasinya tercermin dalam tingkat leverage. Leverage ini juga dengan demikian mencerminkan tingkat resiko keuangan perusahaan. Berdasarkan teori agensi, tingkat leverage mempunyai pengaruh negatif terhadap pengungkapan tanggung jawab sosial. Manajemen perusahaan dengan tingkat leverage yang tinggi cenderung mengurangi pengungkapan tanggung jawab sosial yang dibuatnya agar tidak menjadi sorotan dari para debtholders. (Sembiring, 2005)

Berdasarkan hasil pengujian pengaruh variabel profitabilitas terhadap tingkat pengungkapan CSR, dapat diketahui bahwa variabel profitabilitas secara statistik berpengaruh secara signifikan terhadap tingkat pengungkapan CSR. Hasil ini berarti bahwa besar kecilnya profitabilitas akan mempengaruhi pengungkapan CSR yang dilakukan oleh perusahaan. Perusahaan mengganggap bahwa tanggung jawab sosial sangat penting untuk mengangkat citra perusahaan, oleh karena itu berapapun laba yang diperoleh oleh entitas tidak akan menurunkan atau meningkatkan tanggung jawab sosial yang dilakukan entitas.

Berdasarkan hasil pengujian pengaruh variabel ukuran perusahaan terhadap tingkat pengungkapan CSR, dapat diketahui bahwa variabel ukuran perusahaan secara statistik berpengaruh positif secara signifikan terhadap tingkat pengungkapan CSR. Perusahaan besar memiliki sumber daya yang lebih besar, sehingga berpengaruh secara 
signifikan terhadap luasnya pengungkapan tanggung jawab perusahaan. Temuan ini memberikan implikasi bahwa besar kecilnya ukuran perusahaan akan mempengaruhi luasnya pengungkapan tanggung jawab sosial yang dilakukan. Perusahaan dengan ukuran yang lebih besar dituntut untuk memiliki performance yang lebih tinggi. Salah satu cara untuk memperlihatkan performance yang lebih tinggi adalah dengan lebih memperhatikan kondisi lingkungan sosial, yang dinyatakan dalam pengungkapan CSR yang lebih luas. Selain itu perusahaan yang lebih besar akan melakukan lebih banyak aktivitas yang memberikan dampak yang lebih besar terhadap masyarakat, karena mempunyai lebih banyak pemegang saham yang mungkin berkaitan dengan program sosial perusahaan, sehingga pengungkapan CSR dalam laporan keuangan entitas akan menjadi alat efektif untuk memberikan sinyal ini (Cowen et al., 1987 dalam Sembiring, 2005).

Sesuai dengan teori stakeholder, semakin besar ukuran perusahaan maka tuntutan stakeholder atas manfaat keberadaan perusahaan tersebut cenderung lebih besar. Perusahaan besar akan berusaha mempengaruhi opini publik dan mengurangi tekanan stakeholder dengan jalan pengungkapan yang lebih dan beragam, salah satunya dengan melakukan pengungkapan corporate social responsibility .

Dalam penelitian ini struktur kepemilikan diukur menggunakan presentase outsider stakeholder. Berdasarkan hasil pengujian pengaruh variabel kepemilikan publik terhadap tingkat pengungkapan CSR, dapat diketahui bahwa variabel kepemilikan publik secara statistik berpengaruh secara signifikan terhadap tingkat pengungkapan CSR.

Berdasarkan hasil pengujian hipotesis kelima, ukuran dewan komisaris secara statistik tidak berpengaruh terhadap CSR. Hasil ini berarti bahwa besar kecilnya ukuran dewan komisaris tidak mempengaruhi pengungkapan tanggung jawab sosial perusahaan. Dewan komisaris yang dimiliki perusahaan tidak efektif dalam me-monitoring dan memberikan arahan kepada manajemen perusahaan untuk melakukan pengungkapan CSR berdasarkan GRI. Dewan komisaris perusahaan hanya memberi arahan dan rekomendasi terkait masalah kinerja keuangan. Sewmakin banyak dewan komisaris akan membuat makin banyak kepentingan yang dilakukan dewan komisaris dalam memberi arahan kepada direksi sehingga pengungkapan CSR tidak atas dasar tekanan dewan komisaris yang dimiliki perusahaan. Ukuran dewan komisaris tidak memiliki pengaruh signifikan terhadap pengungkapan tanggung jawab sosial. Penyebabnya karena dewan komisaris merupakan wakil shareholder yang berfungsi mengawasi pengelolaan perusahaan yang dilakukan oleh manajemen, maka dewan komisaris akan membuat kebijakan menggunakan laba perusahaan untuk aktivitas operasional perusahaan yang lebih menguntungkan daripada melakukan aktivitas sosial perusahaan. 


\section{Kesimpulan dan Saran}

Perusahaan harus memiliki leverage yang lebih rendah agar dalam tingkat pengungkapan corporate social responsibility lebih tinggi, bahwa tanggung jawab sosial sangat penting untuk mengangkat citra perusahaan, perusahaan besar tidak akan lepas dari tekanan dan perusahaan yang lebih besar oleh karena itu semakin besar nilai suatu perusahaan maka dalam hal pengungkapan corporate social responsibility semakin tinggi juga, semakin tinggi rasio/ tingkat kepemilikan publik dalam saham perusahaan, maka perusahaan tersebut diprediksi akan melakukan pengungkapan yang lebih tinggi. Hal ini terjadi karena adanya hubungan timbal balik yang kuat antara tanggung jawab perusahaan dengan pihak luar yaitu masyarakat (publik), dan banyaknya dewan komisaris akan semakin meningkatkan kepentingannya terhadap perusahaan.

\section{DAFTAR REFERENSI}

Hernitra, Wellarizma. 2011. Pengaruh Pengungkapan Corporate social responsibility Terhadap Profitabilitas Perusahaan. Fakultas Ekonomi Universitas Jember.

Jalal, 2007. Perkembangan Mutakhir CSR di Indonesia. Catatan CSR sepanjang 2007.

Martereda, Rahmatika. 2011. Analisis Faktor-faktor yang Berpengaruh Terhadap Pengungkapan Pertanggungjawaban Sosial: Studi Empiris pada Perusahaan Manufaktur di Bursa Efek Indonesia. Fakultas Ekonomi Universitas Jember.

Priantinah, D., \& Nur, M. 2012. Analisis Faktor-faktor yang Mempengaruhi Pengugkapan Corporate social responsibility di Indonesia (Studi Empiris pada Perusahaan Berkategori High Profile yang Listing di Bursa Efek Indonesia). Jurnal Nominal Vol. 1 No. 1.

Sembiring, E.R. 2005. Karekteristik Perusahaan dan Pengungkapan Tanggung Jawab Sosial: Study Empiris Pada Perusahaan Yang Tercatat Di Bursa Efek Jakarta. Simposium Nasional Akuntansi VIII, 15-16 September. Solo.

Sembiring, E.R. 2006. Karekteristik Perusahaan dan Pengungkapan Tanggung Jawab Sosial: Study Empiris Pada Perusahaan Yang Tercatat Di Bursa Efek Jakarta. Jurnal Maksi, Vol. 6 No. 1, Januari.

Wijaya, Maria. 2012. Faktor-faktor yang Mempengaruhi Pengungkapan Tanggung Jawab Sosial Pada Perusahaan Manufaktur yang Terdaftar di Bursa Efek Indonesia. Jurnal IImiah Mahasiswa Akuntansi, Januari 2012, Vol. 1 No. 1. 